Historic, Archive Document

Do not assume content reflects current scientific knowledge, policies, or practices. 



\section{A Plantsman}

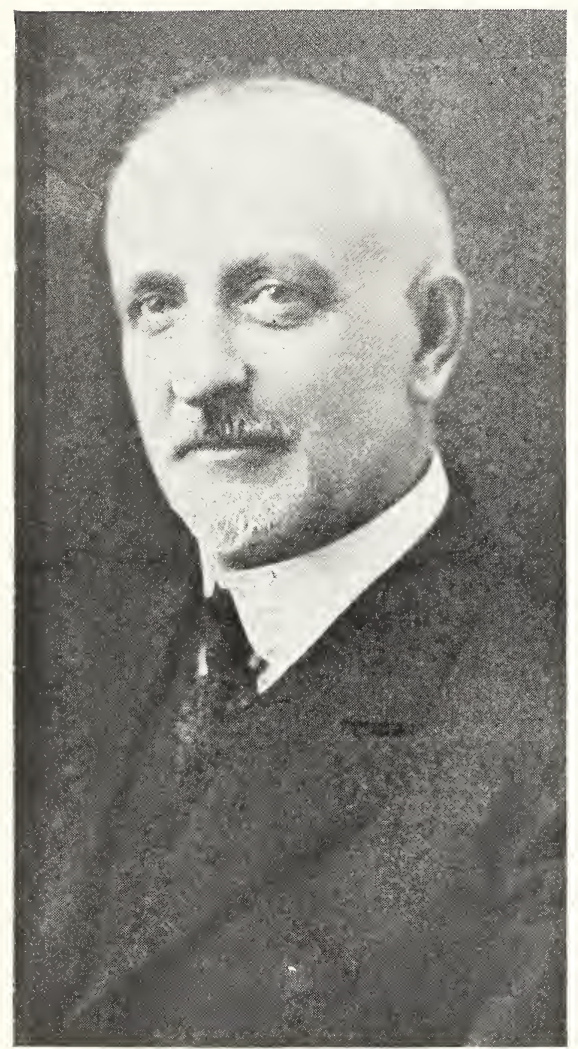

Dr. J. H. Neeley, Paulding, Ohio.

$\mathrm{N}$ each of my several trips to England, I have had most instructive visits with Mr. Amos Perry, the head of the establishment known as Perry's Hardy Plant Farm. He is one of the four 
great "plantsmen" whom I have met. On my last visit with him he made this remark, "One of your American millionaires should establish a fund to develop plantsmen," and in explanation he said that nature has so many secrets in the plant world, which, when made known, will be of such untold value to mankind, that there ought to be a group of men, who without financial worry, could delve into its mysteries.

He believes that when a young man appears at one of our Agricultural or Horticultural Colleges and shows unusual aptitude for the study of flowers and plants, that the way ought to be immediately opened for him to devote his whole life to the intensive study of the trees, shrubs, and plants which he loves. For if he is a real student, he will be able to give back to the world discoveries which will enrich mankind.

Mr. Perry himself seems to be far more of a scientist, a plant scientist, than a commercial grower, and in my several visits with him I have found that the financial side of business is of minor interest to him and the scientific side is the one in which his heart and life are bound up. I am hoping that my nephew, H. Paul Bonnewitz, who this year will graduate from one of our Horticultural colleges may have 
the benefit of an apprenticeship in Mr. Perry's garden.

One of the other great plantsmen whom I have met, is Mr. Henry Correvon of Switzerland. He attended the International Iris Conference in Paris in 1922, and he was kind enough to translate my speech before that body, into French so that it could be understood by practically all the other members of the conference. His knowledge of rock garden plants is said to be greater than that of any other person in the world. Many of my readers no doubt, heard him on his trip through America the past year.

Another of the great plantsmen with whom I have had personal contact is Mr. Hoog, the owner and active manager of the great Holland firm of C. G. Van Tubergen, Jr. The Van Tubergens are dead and Mr. Hoog is a nephew of the founder of the establishment. Mr. Hoog is just as much of a plantsman as Mr. Perry and Mr. Correvon, and he sends expeditions to distant parts of the world to bring specimens of plant life which will enrich our cultivated gardens. His specially built glass houses for propagating difficult species, interested me greatly, and the day spent in his garden will be remembered as one of the most interesting in my life. I am told that such men as Corevon, Hoog and Perry are never happier than 
when they can spend their vacations in each others gardens.

All this however, is but an introduction to the fact that there is at least one great plantsman in America. His name is Dr. J. H. Neeley and he lives in Paulding, Ohio, and while the financial side of our American life has made it necessary for him to devote most of his time to his profession, yet in his ability he is just as great a plantsman as the other three whose names I have given you. Every year many flower lovers from different parts of the United States journey to the little town of Paulding just to sit at the feet of Dr. Neeley and to gain from him an inspiration to study more of the mysteries of the plant world. If, when he left college, he could immediately have been allowed to conduct his study in the plant world without any thought of finances whatever, I am sure that by this time his name would have become famous the world over.

However, he has spent all his spare time upon the study of the plants and shrubs in his own garden. He has originated several new Poppies, the most famous of which is a most beautiful dark red variety named Lula A. Neeley. He has originated over fifty new Peonies, but only three of them, Gloriana, Floweret of Eden, and Pride of Paulding, have yet been named and placed upon the market. 
He has interested himself in Irises and one of his seedlings, a soft yellow variety which is named Golden Promise, has received attention as a promising yellow landscape variety.

The Doctor has developed thousands, yes, I am almost tempted to say hundreds of thousands, of new Gladioli, but of all of these thousands he has given a name to only one which he has called "Beauty's Queen," and it is of such extraordinary merit that I am sure there is a place for it in the catalogs of all progressive "Glad" growers.

As Dr. Neely is not at all commercially inclined and absolutely refuses to sell his own originations, it has been with considerable difficulty that I have secured his permission to offer the very best of his seedlings to my customers. But, at last, having succeeded in getting his permission, I have now made up what I call "A Collection Group of Neeley Seedlings,' which I am offering this season to the growers on my Wholesale list. This collection will contain first, one Poppy, LULA A. NEELEY; second, one division each of the three named Peonies, FLOWERET OF EDEN, PRIDE OF PAULDING, and GLORIANA; third, one rhizome of his yellow Iris, GOLDEN PRONISE; and fourth, one corm of the magnificent Gladiolus, BEA U T Y'S 
QUEEN. The IVholesale collection price on all of these plants will be $\$ 50.00$ and they will be sent prepaid.

I will furnish the same collection, omitting GLORIANA, for $\$ 35.00$, and I will make up a collection containing the Poppy, the Iris and the Glad for $\$ 10.00$.

I hope that all growers who purchase these novelties will give them careful planting in soil with perfect drainage and the necessary sun exposure, because the whole American Horticultural World will be very much interested in the reports from the gardens in which these seedlings are becoming established.

Next year, when you visit our Garden, we hope that you will ask to see all of the "Neeley Seedlings."

LEE R. BONNEWITZ,

Proprietor.

The Bonnewitz

IVHOLESALE

Gardens,

Van Wert,

Ohio.

Oct. 22

1927 